J. Product. \& Dev., 12(1): 13-24 (2007)

\title{
EFFECT OF VITAMIN E AND SELENIUM SUPPLEMENTATION ON GROWTH PERFORMANCE, DIGESTIBILITY, CARCASS TRAITS AND BLOOD COMPONENTS OF BOUSCAT RABBITS.
}

\author{
Rawia, S. Amin* and H. El-Matarawy** \\ * Department of Biochemistry, Faculty of Pharmacy, Zagazig University, Zagazig \\ Egypt. \\ ** Animal Production Research Institute, Agriculture Research Center, Giza, Egypt.
}

\section{ABSTRACT}

Sixty growing Bouscat rabbits 5 weeks old (30 male +30 females) with an average body weight of $(575.33+12.23 \mathrm{~g})$ were divided at random into three comparable groups and fed the following diets. 1) Basal diet without vitamin $E$ and selenium supplementation and served as a control $\left(G_{1}\right)$. 2) Basal diet $+10 \mathrm{mg}$ vitamin E+1mg selenium $\left(G_{2}\right)$. 3) Basal diet+20 mg vitamin E+2mg selenium $\left(G_{3}\right)$. Live body weight, daily weight gain, feed intake and feed conversion were recorded at different age studied. Digestibility of nutrient, nutritive values, carcass traits and blood components were estimated.

The results cleared that, live body weight, daily weight gain and feed conversion were not affected significantly by vitamin $E$ and selenium supplementation. The rabbits of $G 2$ significantly recorded the highest $(P<0.01)$ daily feed intake through 5-13 and 9-13 weeks of the age.

Supplementation with vitamin $E$ and selenium did not significantly affect digestibility of various nutrient and feeding values. The feeding values as TDN and DCP of $G_{2}$ were the highest, followed by $G_{3}$, then $\left(G_{1}\right)$. Dry matter $(D M)$ intake as $\mathrm{g} / \mathrm{head} / \mathrm{day}$ or $\mathrm{g} / \mathrm{kgw}^{0.75}$ or $\mathrm{kg} / \mathrm{kg}$ body weight of the rabbits fed $\mathrm{G}_{2}$ increased than that of the other two groups.

Concentration of globuline, total lipids, alanine and activity of aminotrnsferase (ALT) and alkaline phosphatase were affected significantly ( $P$ $<0.05)$ by vitamin $E$ and selenium supplementation. The alkaline phosphatase activity was increased with increasing the level of vitamin $E$ and selenium supplementation, meanwhile total protein, albumine, urea- $N$, creatinine concentration and AST activity did not affected significantly by vitamin $E$ and selenium supplementation. The carcass \% increased with increasing vitamin $E$ and selenium supplementation, while the kidney and liver percent was decreased with increasing vitamin $E$ and selenium supplementation.

Supplementation of $20 \mathrm{mg}$ vitamin $E+2 \mathrm{mg}$ selenium may be recommended to meet the loss of vitamin $E$ during the diet pelleting and unsuitable storage and to improve productive performance of Bouscat rabbits.

Key words: Vitamin E and selenium, growth performance ,digestibility, blood components, carcass, rabbits. 


\section{INTRODUCTION}

All vitamins and minerals are required for production and reproduction, because of their cellular roles in metabolism, maintenance and growth. However, these nutrients also, may have specific roles and requirements in reproductive tissues.

Vitamin E and selenium are widely distributed in all natural feeds, such as wheat germ oil, oil seeds by-products, grains by-products, all leaf forages, rice polishing, barley grains, oats, rye, sorghum, wheat grains, corn grain meal, corn gluten meal and yeast.

The relationship between vitamin $\mathrm{E}$ and selenium has been was established since, 1950s, when researchers found that selenium prevented exudative diathesis in vitamin E deficient chicks and liver necrosis in vitamin E deficient rats. Subsequent researches demonstrated that deficiency of both vitamin $\mathrm{E}$ and selenium cause reproductive disorders in farm animals such as retained placenta, abortion, metritis, mastitis, and infertility (Larsen, 1993; Wu et al., 1995; Shetaewi, 1998 b; Meshreky and Metry , 2000; Shashi et al., 2002 and Hemingway, 2003).

Vitamin $\mathrm{E}$ is one of the fat soluble vitamins. It acts as an intracellular antioxidant and participates in synthesis of vitamin $\mathrm{C}$ and regulation of DNA metabolism (Scott et al. 1982, Banerjee, 1988 and Nour El-Din, 2000). It also prevents the oxidation of unsaturated fatty acids, present in cell membranes ( Diplock, 1985 and Liebler, 1993). Moreover, vitamin E provides disease resistance by protecting leukocytes and macrophages during phagocytosis and increasing immunity responses (Reddy et al. , 1987).

On the other hand, selenium is a vital component of the enzyme glutathione peroxidase, which reduces cytosolic peroxides and free radicals, i.e. selenium protects the cell from oxidative damage (Pehrson, 1993) and selenium influences the absorption and retention of vitamin $\mathrm{E}$ (Banerjee, 1988). Thus, vitamin $\mathrm{E}$ and selenium together protect the cell from the destructive oxidation reactions. The complementary functions of selenium and vitamin $\mathrm{E}$ have been hypothesized to suggest that supplementation with one can reduce, but not eliminate the requirement for the other (Van Saun et al., 1989). Recently, it was discovered that the deiodinase enzymes which convert $\mathrm{T}_{4}$ (thyroxine, the thyroid prohormone) into $\mathrm{T}_{3}$ (triiodothyronine, the cellularly active hormone) and also convert $T_{3}$ into $T_{2}$, thereby degrading it, are selenium enzymes (formed with the amino acid cysteine). This discovery has led to a lot of research studies on the effects of selenium, iodine and their interactions. It has been found that without selenium, the thyroid gland becomes damaged (Behne et al., 1992 and Wu et al., 1995).

For rabbits nutrition, there are insufficient data in the literature to permit a sound recommendations for the optimum level of vitamin $\mathrm{E}$ and selenium in the diet. Although, several studies showed that level of vitamin $\mathrm{E}$ in the diet decreases with unsuitable storage, pelleting, infecting the diet with molds and presence of unsaturated fatty acids, iron and copper (Dove and Ewan,1987), a level of $40 \mathrm{mg}$ per 
$\mathrm{kg}$ of diet is still suggested (NRC, 1977). Food and drug administration (FDA, 1987) has approved dietary selenium as feed additive up to $0.3 \mathrm{mg} / \mathrm{kg} \mathrm{DM}$ of diet for all major food-producing animals.

The objective of the present study aimed to investigate the effect of adding two levels of vitamin $\mathrm{E}$ and selenium in the drinking water on growth performance, digestibility, some blood serum components, and carcass traits of Bouscat rabbits.

\section{MATERIALS AND METHODS}

The experimental works of the present study was carried out at a commercial (Private) farm at Khatara, Sharkia Governorate.

In this respect, 60 growing Bouscat rabbits 5 weeks old (30 males+ 30 females) with an average initial body weight of $(575.33 \pm 12.23 \mathrm{~g})$ were divided into 3 comparable groups, which to weight were subjected to evaluate the following treatments:

1. The $1^{\text {st }}$ group fed a basal diet without vitamin $\mathrm{E}$ or selenium supplementation and served as control $\left(\mathrm{G}_{1}\right)$

2. The $2^{\text {nd }}$ group fed the same basal diet $+10 \mathrm{mg}$ vitamin $\mathrm{E}+1 \mathrm{mg}$ selenium $\left(\mathrm{G}_{2}\right)$.

3. The $3^{\text {rd }}$ group fed the same basal diet $+20 \mathrm{mg}$ vitamin $\mathrm{E}+2 \mathrm{mg}$ selenium $\left(\mathrm{G}_{3}\right)$.

The ingredients and chemical composition of the basal diet are shown in Table 1.

Vitamin E and selenium were added to drinking water in the form of commercial preparation (vitamin E and selenium), purchased from Mena Vet. Co. Sadat City, Egypt. Rabbit were housed (each 2 together) in wire cages $(60 \times 55 \times 40 \mathrm{~cm})$ provided with feeders and stainless nipple. Feeds and water were offered to rabbits ad libitum during the experimental period. Fresh drinking water either free or supplemented with vitamin $\mathrm{E}$ and selenium were replaced daily. The animals were kept under the same environmental and managerial conditions. The basal diets was formulated in one of feed mills to meet the nutrient requirements of rabbits according to NRC (1977). Live body weight, daily weight gain, feed intake and feed conversion were recorded at four weekly intervals.

Digestibility trials was carried out at the $11^{\text {th }}$ week of age using 3 male rabbits from each experimental groups. The rabbits were housed individually in metabolic cages. The trial lasted 10 days, 4 days as a preliminary period followed by 6 days as a collection period. Daily feces of each rabbit were taken and oven dried at $65{ }^{0} \mathrm{C}$ for 48 hour, then ground and stored until the time of chemical analysis. Chemical analysis of samples of feed and feces were performed according to A. O. A. C. (1990). The metabolizable energy (ME) of the diet were calculated according to the equation described by Kalogen (1985) as follows:

$\mathrm{ME}(\mathrm{kcal} / \mathrm{kg}$ diet $\mathrm{DM})=(0.588+0.164 \mathrm{x}) 239$, where $\mathrm{x}$ is a dry matter digestion coefficient of tested diet. The values of TDN were calculated according to the classic formula of Cheeke et al. (1982). 
At 13 weeks of age, 3 rabbits from each experimental group were randomly slaughtered. Blood samples were taken from each rabbit at the time of slaughtering. Blood serum was separated by centrifugation at 3000 r.p.m. for 15 minutes and stored frozen $\left(-20^{0} \mathrm{c}\right)$ in plastic vials until performance of the biochemical tests. Levels of serum total protein, albumen, total lipids, urea-N, creatinine, aspartate aminotransferase (AST) and alanine aminotrnsferase (ALT) were determined using a calorimetric assay kits, following the methodology suggested by the procedures.

Table 1. Ingredients and chemical analysis of the basal diet.

\begin{tabular}{lc}
\hline Items & $\%$ \\
\hline Composition of the diet & 23.00 \\
Yellow corn grains & 31.00 \\
Wheat bran & 30.00 \\
Clover hay & 14.00 \\
Soybean meal & 1.00 \\
Limestone & 0.25 \\
Bone meal & 0.25 \\
${ }^{1}$ Premix & 0.50 \\
Sodium chloride (common salt) & \\
Chemical analysis: & 89.91 \\
Dry matter (DM) & 81.05 \\
Organic matter (OM) & 16.55 \\
Crude protein (CP) & 4.08 \\
Ether extract (EE) & 13.13 \\
Crude fiber ( CF) & 47.29 \\
Nitrogen free extract (NFE) & 8.86 \\
Ash & 0.88 \\
${ }^{2}$ Calcium & 0.64 \\
${ }^{3}$ Phosphorus & 0.56 \\
${ }^{4}$ Methionine + cystine & 0.83 \\
${ }^{5}$ Iodine (ppm) & 0.24 \\
${ }^{6}$ Selenium (ppm) & 68.00 \\
Vitamin E (ppm) & 167. \\
\hline
\end{tabular}

${ }^{1}$ One kilogram of premix contained: Vit. A 4000000 IU, Vit. $\mathrm{D}_{3} 50000 \mathrm{IU}$, Vit. E 16.7 gm, Vit. $\mathrm{K}_{3}$ $0.67 \mathrm{gm}$, Vit. $\mathrm{B}_{1} 0.67 \mathrm{gm}$, Vit. $\mathrm{B}_{2} 2.0 \mathrm{gm}$, Vit. $\mathrm{B}_{6} 0.67 \mathrm{gm}$, Vit. $\mathrm{B}_{12} 3.33 \mathrm{mg}$, Choline chloride $400 \mathrm{gm}$, 
Biotin $0.07 \mathrm{gm}$, Niacin $16.7 \mathrm{gm}$, Pantothenic acid $6.7 \mathrm{gm}$, Folic acid $1.7 \mathrm{gm}$, Magnesium $133.3 \mathrm{gm}$, Copper $1.7 \mathrm{gm}$, Iodine $0.25 \mathrm{gm}$, Selenium $33.3 \mathrm{mg}$, Iron $25 \mathrm{gm}$, Manganese $10 \mathrm{gm}$ and Zinc $23.3 \mathrm{gm}$.

2,3,4 The values were calculated according to NRC (1977).

${ }^{5}$ Iodine was calculated according to Kalashnikov and Klemenov (1985).

${ }^{6}$ Selenium was calculated according to Ensminger et al. (1990).

Data of the experiment were statistically analyzed according to Snedecor and Chochran (1982), using SPSS system (1998). The differences between means were tested using Duncan's New Multiple Rang Test (Duncan,1955).

\section{RESULTS AND DISCUSSION}

\section{Growth performance:}

Data in Table 2 indicated that there were no significant differences in live body weight daily weight gain or feed conversion among the experimental groups. The rabbits gained over 8 weeks (5-13 weeks old) $1601.43,1652.29$ and $1652.00 \mathrm{~g}$ for $\mathrm{G}_{1}, \mathrm{G}_{2}$ anG $\mathrm{G}_{3}$, corresponding to $28.60,29.51$ and $29.50 \mathrm{~g}$, respectively. However, feed intake significantly increased in $\mathrm{G}_{2}(0.01)$ starting from $9^{\text {th }}$ week of age up to the end of the experiment at the $13^{\text {th }}$ week of age as compared to either $\mathrm{G}_{1}$ or $\mathrm{G}_{3}$, Table 2 . Then respective increase in feed intake was 8.36 and $8.05 \%$, respectively.

Table 2. Effect of supplementation of Vitamin $E$ and selenium on growth performance $(\mathrm{X} \pm \mathrm{SE})$ of growing Bouscat rabbits.

\begin{tabular}{lccc}
\hline \multicolumn{1}{c}{ Items } & \multicolumn{3}{c}{ Experimental groups } \\
\cline { 2 - 4 } & $\mathbf{G}_{\mathbf{1}}$ ( Control) & $\mathbf{G}_{\mathbf{2}}$ & $\mathbf{G}_{\mathbf{3}}$ \\
\hline No. of rabbits & 20 & 20 & 20 \\
Initial body weight at 5 weeks(g): & $575.00 \pm 18.81$ & $562.00 \pm 15.31$ & $588.00 \pm 20.60$ \\
Live body weight at age 9 weeks & $1477.86 \pm 35.57$ & $1443.33 \pm 59.46$ & $1532.35 \pm 54.45$ \\
Live body weight at age 13 weeks & $2176.43 \pm 26.59$ & $2214.29 \pm 58.65$ & $2240.00 \pm 61.07$ \\
Daily weight gain (g) from age: & & & \\
$\quad$ 5-9 weeks & $32.78 \pm 1.45$ & $31.48 \pm 1.99$ & $33.47 \pm 1.68$ \\
9-13 weeks & $24.95 \pm 1.03$ & $27.81 \pm 1.65$ & $25.27 \pm 1.37$ \\
5-13 weeks & $28.60 \pm 0.52$ & $29.51 \pm 0.88$ & $29.50 \pm 1.04$ \\
Daily feed intake (g/day) from age: & & & \\
5-9 weeks & $114.14 \pm 2.13$ & $119.14 \pm 1.52$ & $114.06 \pm 2.02$ \\
9-13 weeks & $157.11 \pm 2.29^{\mathrm{b}}$ & $170.25 \pm 3.22^{\mathrm{a}}$ & $157.56 \pm 3.55^{\mathrm{b}}$ \\
5-13 weeks & $135.63 \pm 1.56^{\mathrm{b}}$ & $144.69 \pm 1.48^{\mathrm{a}}$ & $135.81 \pm 1.90^{\mathrm{b}}$ \\
Feed conversion ratio (g feed/g gain) from age: & & \\
5-9 weeks & $4.41 \pm 0.38$ & $4.10 \pm 0.54$ & $3.66 \pm 0.82$ \\
9-13 weeks & $5.41 \pm 0.33$ & $5.46 \pm 0.32$ & $5.23 \pm 0.45$ \\
5-13 weeks & $4.74 \pm 0.30$ & $4.90 \pm 0.50$ & $4.60 \pm 0.35$ \\
\hline
\end{tabular}

Means in the same row having different superscript differ significantly $(\mathrm{P}<0.01)$. 
Feed conversion was $4.74 \mathrm{~g}$ feed/g gain in the control group. It tended to slightly increased to be $4.90 \mathrm{~g}$ ration/g gain in $\mathrm{G}_{2}$ versus a slight decrease to $4.60 \mathrm{~g}$ ration/g gain in $\mathrm{G}_{3}$. Thus it could be concluded that the feed conversion was improved by the highest rate of vitamin E and selenium supplementation. Abdel-Samee and ElMasry (1997) reported that NZW growing rabbits supplemented with Vitamin E + selenium showed higher gain $\quad(\mathrm{P}<0.01)$ than unsupplemented group. The disagreement of our results with that obtained by other researchers may be due to the differences in the levels used of vitamin $\mathrm{E}$ and selenium and the route of supplementation, in the drinking water or in the ration.

\section{Digestibility of nutrient and nutritive value:}

Digestibility of nutrients and feeding values from the data are shown in Table 3. It is noticed that the DM intake expressed as $\mathrm{g} / \mathrm{head} / \mathrm{day}$ or $\mathrm{g} / \mathrm{kgw}^{0.75}$ or $\mathrm{kg} / \mathrm{kg}$ body weight of the rabbits of $\mathrm{G}_{2}$ supplemented with $10 \mathrm{mg}$ vitamin $\mathrm{E}+1 \mathrm{mg}$ selenium increased than that of control group or $\mathrm{G}_{3}$ supplemented with $20 \mathrm{mg}$ vitamin $\mathrm{E}+2$ $\mathrm{mg}$ selenium. However, supplementation with vitamin $\mathrm{E}$ and selenium did not significantly affect digestibility of various nutrients or feeding value. It clearly appears that supplementation rabbits with $10 \mathrm{mg}$ vitamin $\mathrm{E}+1 \mathrm{mg}$ selenium recorded the best value of DM, OM, and NFE digestibility, meanwhile $\mathrm{G}_{3}(20 \mathrm{mg}$ vitamin $\mathrm{E}$ $+2 \mathrm{mg}$ selenium) recorded the best value of $\mathrm{CP}$ and $\mathrm{EE}$ digestibility coefficients.

The feeding values as TDN and DCP of $\mathrm{G}_{2}$ was the highest values, followed by $\mathrm{G}_{3}$, and the least was the control group. It concluded that supplementation of vitamin $\mathrm{E}$ and selenium increased the digestibility of $\mathrm{DM}, \mathrm{OM}$ and $\mathrm{CP}$ than that of the control diet. While the digestibility of $\mathrm{CF}$ and EE showed an opposite trend. Also the nutritive values as TDN and DCP $\left(\mathrm{g} / \mathrm{kg} \mathrm{w}^{0.75}\right)$ increased than that of the control group.

\section{Carcass traits:}

Data in Table 4 showed that supplementation with vitamin $\mathrm{E}$ and selenium did not significantly affect the dressed weight $\%$, carcass weight $\%$, digestive tract weight $\%$, head and kidney weight $\%$, liver weight $\%$ and heart weight $\%$. The carcass $\%$ increased with increasing vitamin $\mathrm{E}$ and selenium supplementation level, while digestive tract, head, kidney, liver and heart \% were decreased. Similar results were reported by Shetaewi (1998), who found that vitamin E supplementation did not affect hot carcass weight of NZW rabbits. Also, Meshreky et al. (2002) found that percentages of dressing, liver and kidney weights decreased $(\mathrm{P}<0.05)$ in male rabbits injected with vitamin E plus selenium as compared to the control rabbits. It could be noticed that, the kidney and liver percent decreased with increasing vitamin $\mathrm{E}$ and selenium supplementation which may be due to effect of vitamin $\mathrm{E}$ and selenium as antioxidant (Scott et al. 1982, Diplock, 1985, Banerjee, 1988, Liebler, 1993, and Nour El-Din, 2000). 
Table 3. Digestion coefficient and nutritive values of growing rabbits fed diet supplemented with vitamin $E$ and selenium.

\begin{tabular}{|c|c|c|c|}
\hline Items & $\mathbf{G}_{1}$ (Control) & $\mathbf{G}_{2}$ & $\mathbf{G}_{\mathbf{3}}$ \\
\hline $\begin{array}{l}\text { Nutrients digestibility (\%) } \\
\text { Number of animals: }\end{array}$ & 3 & 3 & 3 \\
\hline \multicolumn{4}{|l|}{ Average initial weight: } \\
\hline $\mathrm{Kg}$ & $2.88 \pm 0.15$ & $2.60 \pm 0.09$ & $2.41 \pm 0.14$ \\
\hline $\mathrm{kg} \mathrm{W}^{0.75}$ & $2.21 \pm 0.09$ & $2.05 \pm 0.01$ & $1.94 \pm 0.09$ \\
\hline \multicolumn{4}{|l|}{ Dry matter intake: } \\
\hline $\mathrm{kg} / \mathrm{kg} \mathrm{BW}$ & $4.96 \pm 0.21$ & $5.59 \pm 0.19$ & $5.35 \pm 0.29$ \\
\hline G/head/day & $124.62 \pm 6.38$ & $145.10 \pm 4.18$ & $130.17 \pm 5.43$ \\
\hline $\mathrm{G} / \mathrm{kg} \mathrm{W}^{0 . / 2}$ & $64.69 \pm 2.47$ & $70.80 \pm 2.31$ & $67.30 \pm 2.19$ \\
\hline $\begin{array}{l}\text { Digestion coefficient }(\%) \text { : } \\
\text { DM }\end{array}$ & $57.57 \pm 1.35$ & $61.30 \pm 2.63$ & $61.17 \pm 1.44$ \\
\hline $\mathrm{OM}$ & $63.91 \pm 0.43$ & $64.95 \pm 1.87$ & $64.86 \pm 0.91$ \\
\hline $\mathrm{CP}$ & $69.28 \pm 0.25$ & $69.62 \pm 2.43$ & $69.71 \pm 0.42$ \\
\hline $\mathrm{CF}$ & $33.80 \pm 0.45$ & $32.13 \pm 1.85$ & $30.16 \pm 2.31$ \\
\hline $\mathrm{EE}$ & $83.34 \pm 2.19$ & $72.06 \pm 1.79$ & $70.59 \pm 0.87$ \\
\hline NFE & $71.40 \pm 1.42$ & $72.06 \pm 1.79$ & $70.59 \pm 0.87$ \\
\hline \multirow{2}{*}{\multicolumn{4}{|c|}{$\begin{array}{l}\text { Nutritive values: } \\
\text { TDN }\end{array}$}} \\
\hline & & & \\
\hline G/head/day & $89.31 \pm 3.56$ & $88.85 \pm 3.38$ & $80.53 \pm 3.66$ \\
\hline $\mathrm{G} / \mathrm{kg} \mathrm{W}^{0.75}$ & $40.55 \pm 1.85$ & $44.48 \pm 0.58$ & $41.61 \pm 1.23$ \\
\hline \multicolumn{4}{|l|}{$\operatorname{DCP}(\%)$} \\
\hline G/head/day & $17.36 \pm 0.64$ & $17.89 \pm 0.12$ & $61.11 \pm 0.76$ \\
\hline $\mathrm{G} / \mathrm{kg} \mathrm{W}^{0 . / 15}$ & $7.89 \pm 0.33$ & $8.73 \pm 0.05$ & $8.33 \pm 0.31$ \\
\hline $\mathrm{DE}(\mathrm{kcal})$ & $1805.96 \pm 76.86$ & $1697.25 \pm 66.19$ & $1669.57 \pm 61.78$ \\
\hline
\end{tabular}

All the differences among means in the same row were not significant.

DE (kcalkg)= DCP x $8.25 \mathrm{~g} / \mathrm{kg}+$ DEE x $9.51 \mathrm{~g} / \mathrm{kg}+$ DCF x $4.20 \mathrm{~g} / \mathrm{kg}+\mathrm{NFE}$ x $4.20 \mathrm{~g} / \mathrm{kg}$ (Schieman et al. (1972). 
Table 4. Carcass traits of growing rabbits fed diet supplemented with vitamin $\mathrm{E}$ and selenium

\begin{tabular}{|c|c|c|c|}
\hline \multirow{2}{*}{ Items } & \multicolumn{3}{|c|}{ Experimental groups } \\
\hline & $\overline{G_{1} \text { (Control) }}$ & $\mathbf{G}_{2}$ & $\overline{G_{3}}$ \\
\hline Preslaughter weight (g) & $2000.00 \pm 150.98$ & $2150.00 \pm 68.07$ & $2196.67 \pm 54.87$ \\
\hline Dressed weight $(\mathrm{g})$ & $1215.16 \pm 89.01$ & $1316.24 \pm 49.23$ & $1357.17 \pm 66.25$ \\
\hline$(\%)$ & 57.32 & 55.03 & 58.16 \\
\hline Carcass weight $(\mathrm{g})$ & $1006.67 \pm 121.29$ & $1100.00 \pm 57.54$ & $1153.33 \pm 56.96$ \\
\hline$(\%)$ & 50.33 & 51.16 & 52.56 \\
\hline Digestive tract weight (g) & $350.00 \pm 28.78$ & $396.67 \pm 21.86$ & $386.637 \pm 3.33$ \\
\hline$(\%)$ & 17.50 & 18.45 & 17.60 \\
\hline Head weight $\quad(g)$ & $113.33 \pm 8.82$ & $126.67 \pm 8.82$ & $116.67 \pm 4.71$ \\
\hline$(\%)$ & 5.67 & 5.89 & 5.31 \\
\hline Kidney weight (g) & $23.50 \pm 3.25$ & $17.57 \pm 1.70$ & $17.17 \pm 0.82$ \\
\hline$(\%)$ & 1.18 & 0.82 & 0.78 \\
\hline Liver weight (g) & $72.33 \pm 7.88$ & $72.00 \pm 10.21$ & $70.00 \pm 2.08$ \\
\hline$(\%)$ & 3.62 & 3.35 & 3.19 \\
\hline Heart weight (g) & $5.97 \pm 0.47$ & $5.73 \pm 0.52$ & $6.93 \pm 0.39$ \\
\hline$(\%)$ & 0.30 & 0.27 & 0.32 \\
\hline
\end{tabular}

*All the differences among means in the same row were not significant.

\section{Blood serum components:}

Data of blood analysis are shown in Table 5. It clearly appears that the total protein, albumin, urea-N, creatinine and AST were not affected significantly by vitamin $\mathrm{E}$ and selenium supplementation. The values of these parameters are within the normal range.

The globulin value of rabbit of $\mathrm{G}_{3}(20 \mathrm{mg}$ vitamin $\mathrm{E}+2 \mathrm{mg}$ selenium) was significantly $(P<0.05)$ higher than that of $G_{2}(10 \mathrm{mg}$ vitamin $E+1 \mathrm{mg}$ selenium $)$. Total lipids $(P<0.05)$, ALT and alkaline phosphatase $(P<0.01)$ of rabbits of $G_{2}(10$ $\mathrm{mg}$ vitamin $\mathrm{E}+1 \mathrm{mg}$ selenium) and $\mathrm{G}_{3}(20 \mathrm{mg}$ vitamin $\mathrm{E}+2 \mathrm{mg}$ selenium) were significantly higher than that control diet, but the differences in this respect between rabbits of $\mathrm{G}_{2}$ and $\mathrm{G}_{3}$ were insignificant. From the data in Table 5 it could be noticed that total lipids, urea-N, creatinine, AST, ALT and Alkaline phosphatase increased with increasing vitamin $\mathrm{E}$ and selenium supplementation from $10 \mathrm{mg}$ vitamin $\mathrm{E}+1$ $\mathrm{mg}$ selenium to $20 \mathrm{mg}$ vitamin E $+2 \mathrm{mg}$ selenium. El-Husseiny et al. (1997) and Shetaewi (1998b) found an increase in blood plasma total protein in response to vitamin E supplementation. Also, Zeidan et al. (2001) and Gad Alla et al. (2002) reported that buck rabbits given vitamin $\mathrm{E}$ had higher values in blood total protein, albumin and globulin than those fed the control diet.On the contrary, Youssef et al. (2003) found that treatment of rabbits with vitamin E significantly decreased ( $\mathrm{P}<$ 
0.05) the activities of aspartate aminotransferase (AST), alanine aminotransferase (ALT).

Table 5. Effect of supplementation of vitamin $E$ and selenium on some blood serum components $(\mathrm{X} \pm \mathrm{SE})$ of rabbits.

\begin{tabular}{lccc}
\hline \multirow{2}{*}{ Items } & \multicolumn{3}{c}{ Experimental groups } \\
\cline { 2 - 4 } & $\mathbf{G}_{\mathbf{1}}(\mathbf{C o n t r o l})$ & $\mathbf{G}_{\mathbf{2}}$ & $\mathbf{G}_{\mathbf{3}}$ \\
\hline Total protein $(\mathbf{g} / \mathbf{d l})$ & $5.41 \pm 0.12$ & $5.33 \pm 0.23$ & $5.41 \pm 0.24$ \\
Albumin $(\mathbf{g} / \mathbf{d l})$ & $4.09 \pm 0.26$ & $3.80 \pm 0.12$ & $3.45 \pm 0.18$ \\
Globulin $(\mathbf{g} / \mathbf{d l})$ & $1.88 \pm 0.41^{\mathrm{ab}}$ & $1.53 \pm 0.20^{\mathrm{b}}$ & $1.95 \pm 0.07^{\mathrm{a}}$ \\
Albumin/ Globulin ratio & $2.18 \pm 0.38^{\mathrm{ab}}$ & $2.48 \pm 0.31^{\mathrm{a}}$ & $1.77 \pm 0.09^{\mathrm{b}}$ \\
Total lipid (mg/dl) & $284.50 \pm 16.45^{\mathrm{b}}$ & $311.56 \pm 20.32^{\mathrm{a}}$ & $320.72 \pm 35.16^{\mathrm{a}}$ \\
Urea- $\mathbf{N}(\mathbf{m g} / \mathbf{d l})$ & $21.18 \pm 5.58$ & $22.47 \pm 6.31$ & $23.35 \pm 7.81$ \\
Creatinine (mg/dl) & $1.21 \pm 0.14$ & $1.43 \pm 0.05$ & $1.45 \pm 0.14$ \\
AST $(\boldsymbol{\mu} / \mathbf{L})$ & $8.01 \pm 0.54$ & $6.06 \pm 0.20$ & $10.3 \pm 0.77$ \\
ALT $(\boldsymbol{\mu} / \mathbf{L})$ & $14.19 \pm 0.50^{\mathrm{b}}$ & $18.64 \pm 1.12^{\mathrm{a}}$ & $18.74 \pm 0.11^{\mathrm{a}}$ \\
Alkaline Phosphatase $(\boldsymbol{\mu} / \mathbf{L})$ & $12.29 \pm 0.52^{\mathrm{b}}$ & $20.56 \pm 1.26^{\mathrm{a}}$ & $23.84 \pm 0.13^{\mathrm{a}}$ \\
\hline
\end{tabular}

Means in the same row having different superscript differ significantly $(\mathrm{P}<0.05)$.

\section{In conclusion}

Vitamin E and selenium are necessary for the normal growth, whereas it significantly increased the daily feed intake insignificantly increased the daily body gain and improved feed conversion specially by supplementation of $10 \mathrm{mg}$ vitamin $\mathrm{E}$ $+1 \mathrm{mg}$ selenium) . Also, improved digestibility of most nutrient and feeding values, moreover improved liver transaminase and kidney function and carcass traits. Adding in the drinking water a level of $10 \mathrm{mg}$ vitamin $\mathrm{E}+1 \mathrm{mg}$ selenium /liter may be recommended as a complementary level to compensate the loss of vitamin $\mathrm{E}$ during the diet pelleting and unsuitable storage and to improve productive performance of Bouscat rabbits.

\section{REFERENCES}

Abdel-Samee, A. M. and El-Masry, K. A. (1997). Effects of varying copper levels or selenium with vitamin $\mathrm{E}$ supplementation on growth and reproductive performance of New Zealand White rabbits under subtropical conditions. Egypt. Poultry Science, 17: 133-149.

A. O. A. C. (1990). Association of Official Analytical Chemists, "Official Methods of Analysis". $13^{\text {th }}$ edition Published by the A. O. A .C., Benjamen Franklin Station, Washington, D. C.

Banerjee, G. C. (1988). Feeds and Principles of Animals Nutrition. $2^{\text {nd }}$ Edition, Oxford and IBH Publishing Co. PVT. LTD.

Behne, D. , Kyriakopoulos, A.; Gessner, H.; Walzog, B. and Meinhold, H. (1992). Type I iodothyronine deiodinase activity after high selenium intake 
and relations between selenium and iodine metabolism in rats. Journal of Nutrition, 122 (7) : 1542-1546.

Cheeke, P.R., Patton, N. M. and Tempelton, G. S. (1982). Rabbit Production. The $5^{\text {th }}$ edition, Interstate Printers and Publishers, Danville 11.

Diplock, A.T. (1985). Vitamin E. In: "Fat-Soluble Vitamins ."William Heinemann Ltd., London.

Dove, C. R. and Ewan, R. C. (1987). The effect of diet composition and storage on the stability of vitamin E. Journal Animal Science, 65 (Suppl. 1): 302.

Duncan, D.B. (1955). Multiple Range and Multiple F-Test. Biometrics, 11: 1- 42.

El-Husseiny, O.; Ghazala, A.A. ; Arafa, S. A.; Omar , N. F. and El-Manyalawy, M. A. (1997). Effect of vitamin A and E level and their interaction on the growth performance of growing rabbits. Egyptian J. Rabbit Science, 7: 13-25.

Ensminger, M. E.; Oldfield J. E. and Heinemann, W. W. (1990). Feeds and Nutrition. The $2^{\text {nd }}$ edition, The Ensminger Publishing Compony, Clovis, California, USA.

FDA, Food and Drag Administration (1987). Food additives permitted in feed and drinking water of animals: Selenium. Fed. Reg., 52: 10668.

Gad Alla, S. A. ; Metwally, A. M.; Mervat M. Arafa and Abowarda, M. A. (2002). Effect of vitamin $C$ and E supplementation on blood constituents and reproductive performance in buck and doe rabbits. $3^{\text {rd }}$ Science Conference On Rabbit Production in Hot Climates, 8-11 Oct: 705-714.

Hemingway, R.G. (2003). The influences of dietary intakes and supplementation with selenium and vitamin $\mathrm{E}$ on reproduction diseases and reproductive efficiency in cattle and sheep. Veterinary Research Communications, 27(2): 159-174.

Kalashnikov, A. P. and Klemenov, N. E. (1985). Feeding Standards and Rations of Farm Animals (In Russian). Agropromozdat Publishing, Moscow, Russia.

Kalogen, U. A. (1985). Rabbits Nutrition (In Russian). A gropomezdat Publishing, Moscow, Russia.

Larsen, H.J.S. (1993). Relations between selenium and immunity. Norwegian Journal Agriculture Science, (supplement) 11: 105.

Liebler, D. C. (1993). The role of metabolism in antioxidant function of vitamin E. Crit Rev. Toxicol, 23: 147-169.

Meshreky Samia, Z. ;Iman , Shaheed B. and Metry, G. H. (2002) . Effect of vitamin $\mathrm{E}$ and /or selenium on puberty, maturity, some anatomical and histopathological parameters of male genitalia of rabbits weaned during summer of middle Egypt. $3^{\text {rd }} \mathrm{Sci}$. Con. On Rabbit Production in Hot Climates, 8-11 Oct.:183-203.

Meshreky Samia, Z. and Metry, G. H. (2000). Effect of vitamin E and /or selenium injection on 1- Reproductive performance of New Zealand White and Baladi doe rabbits under climate conditions of middle Egypt. In The Proceeding of 
$3^{\text {rd }}$ All Africa Conference on Animal Agriculture and $11^{\text {th }}$ Conference of the Egypt Society of Animal Production, 6-9 Nov, Alexandria, Egypt.

N.R.C. (1977). Nutrient Requirements of Rabbits. $2^{\text {nd }}$ Review. Edition. National Academy Science, USA.

North, M. O. (1981). Commercial Chicken Production. Manual $2^{\text {nd }}$ Ed. Library of Congress. AVI Publishing Company Inc., USA.

Nour El-Din, E. (2000). Biochemistry for medical students 1. Vitamins Hormones. Modern Islamic Press, Helymiat El-Zaitoun, Cairo, 185-210.

Pehrson, B.G. (1993). Selenium in nutrition with special reference to the biopotency of organic and inorganic compounds. Page 71 in Biotechnology in the Feed Industry. Proceeding Alltech's $9^{\text {th }}$ Annual Symposium, Nicholasville, KY.

Reddy, P.G., Morrill, J.L.; Minocha, H. C. and Stevenson, J. S. (1987). Vitamin E is immunostimulatory in calves. J. Dairy Science, 70: 993-999.

Scott, M. L.; Nesheim, M. C. and Young, R. T. (1982). Nutrition of the Chicken. P.165 Scott, Ithaca, N. Y.

Shashi, N.; GilK, V. K.; Narinder, S.; Roy, K. S.; Rajvir, S.; Nayyar, S.; Singh, N. and Singh, R. (2002). Levels of antioxidant vitamins in anoestrus buffalo heifers supplemented with vitamin $\mathrm{E}$ and selenium. Indian Journal of Animal Sciences, 72 (5): 395-397. ref.

Shetaewi, M. M. (1998). Effects of dietary supplemental vitamin E on reproduction, growth and carcass traits of rabbits. Egyptian J. Nutrition \& Feeds, 2: 87-96.

Shetaewi, M. M. (1998b). Effects of dietary supplemental vitamin E on reproduction, growth and carcass traits of rabbits. Egyptian Journal Nutrition \& Feeds, 1: 87-96.

Snedecor, G.W. and Cochran, W.G. (1982). Statistical Methods. $7^{\text {th }}$ Edition. Iowa State. University, Press, USA.

SPSS (1998). User's Guide Statistics Version, 8. Copyright SPSS Inc. USA.

Van Saun, R. J.; Herdt, T. H. and Stowe, H. D. (1989). Maternal and fetal vitamin $\mathrm{E}$ concentrations and selenium-vitamin $\mathrm{E}$ interrelationships in dairy cattle. Journal Nutrition, 119: 1128.

Wu HY; Xia Y. M. and Chen, X. S. (1995). Selenium deficiency and thyroid hormone metabolism and function. Sheng Li Ko Hsueh Chin Chan, 26 (1):1216.

Youssef, .M.I. ; Abdallah, G. A. and Kamel, K. I. (2003). Effect of ascorbic acid and Vitamin E supplementation on semen quality and biochemical parameters of male rabbits. Animal Reproduction Science, 76 (1-2): 99-111.

Zeidan, A. E. B.; Daader, A. H.; Hanna, M. F. S.; Hamouda, I. A. and Seleem, T. S. T. (2001). Some productive and reproductive traits of male rabbits as affected by vitamin $\mathrm{E}$ and selenium administeration under hot climatic conditions. Egyptian Journal of Nutrition and Feeds, 4 (Special Issue):897908 . 
تأثير إضافة فيتامين هـ و السيلينيوم على معدل النمو ومعاملات الهضم وصفات الذبيحة ومكونات سيرم الام في الأرانب البوسكات.

$$
\begin{aligned}
& \text { راوية أمين سرحان* ـ حمدي المطراوي * مارئ }
\end{aligned}
$$

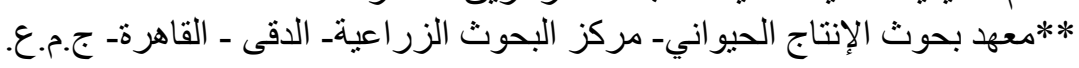

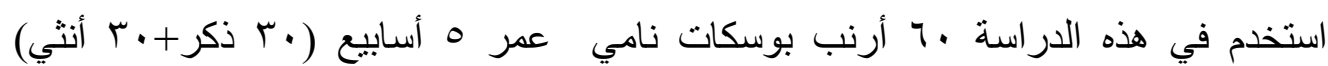

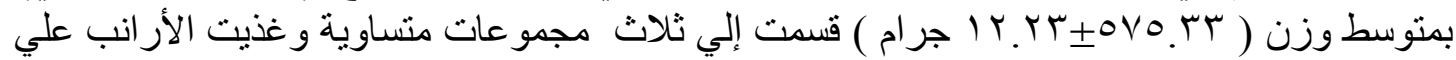

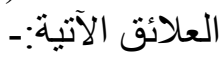

ا ــ الدجمو عة الأولى على العليقة الأساسية بدون أي إضافة و اتخذت للمقارنة.

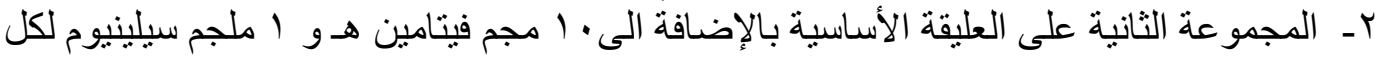

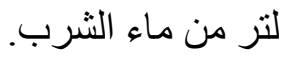
r- المجموعة الثالثة على العليقة الأساسية بالإضافة إلى •ب مجم فيتامين هـ و r ملجم سيلينيوم

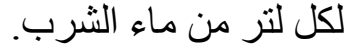

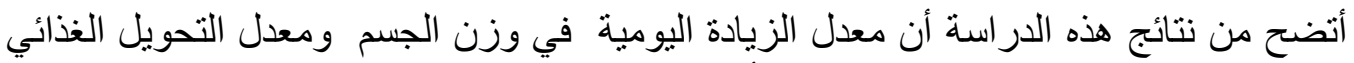

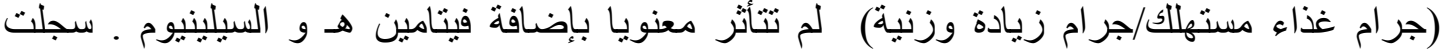

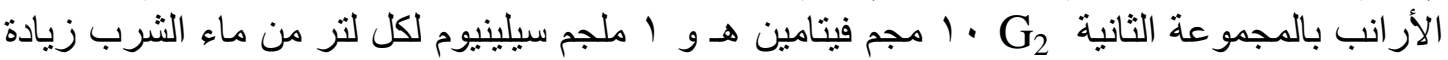

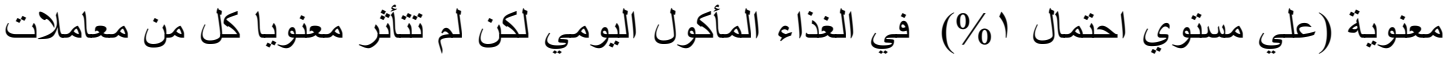

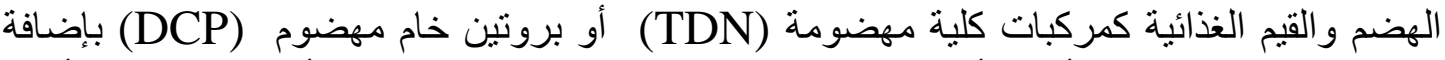

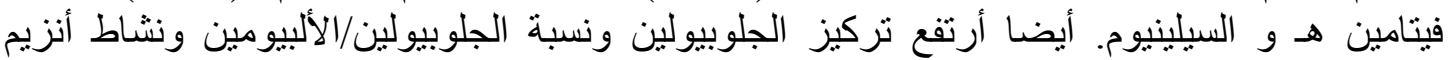
AST and ALT

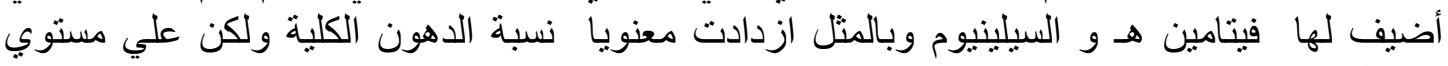
احتمال 0\%

تتير النتائج إلي حدوث بعض التحسن في معدل الأداء الإنتاجي في الأرانب البوسكات التي لتئي

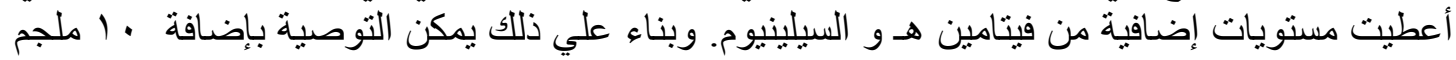

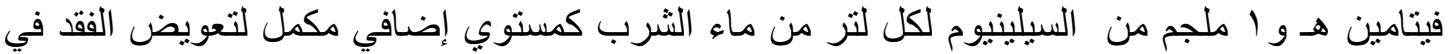
فيتامين هـ خلال عملية تصنيع العلائق و ظروف لـن التخزين الغير مناسبة. 